Relations industrielles

Industrial Relations

\title{
Inflation : Demand-Pull or Cost-Push? Edited by Richard Perlman, D.C. Heath and Company, Boston, 1965. 130 pages.
}

\section{André Petit}

Volume 21, numéro 3, 1966

URI : https://id.erudit.org/iderudit/027720ar

DOI : https://doi.org/10.7202/027720ar

Aller au sommaire du numéro

Éditeur(s)

Département des relations industrielles de l'Université Laval

ISSN

0034-379X (imprimé)

1703-8138 (numérique)

Découvrir la revue

Citer ce compte rendu

Petit, A. (1966). Compte rendu de [Inflation : Demand-Pull or Cost-Push? Edited by Richard Perlman, D.C. Heath and Company, Boston, 1965. 130 pages.] Relations industrielles / Industrial Relations, 21(3), 468-469.

https://doi.org/10.7202/027720ar

Tous droits réservés @ Département des relations industrielles de l'Université Laval, 1966
Ce document est protégé par la loi sur le droit d'auteur. L’utilisation des services d'Érudit (y compris la reproduction) est assujettie à sa politique d'utilisation que vous pouvez consulter en ligne.

https://apropos.erudit.org/fr/usagers/politique-dutilisation/ 
ments \# fonctionnels il existe toujours une autorité hiérarchique. Ce serait là une façon de reconcilier les deux perspectives au risque d'un mécontentement de la part de l'auteur puisqu'il soutient que l'autorité hiérarchique est déléguée sur des personnes et l'autorité fonctionnelle sur des activités.

Une autre remarque porte sur les types de structure et la taille des entreprises. D'abord, les critères qui permettent de classifier les entreprises selon leur taille ne sont pas clairs. Quelle est la différence exacte entre la grande et la très grande entreprise?

En classifiant les structures en référant aux types de relations d'autorité, l'auteur découvre que les relations d'autorité «staff and line » caractérisent la petite entreprise oussi bien que la très grande entreprise. Un malin pourrait conclure que la dimension de l'entreprise influence peu la structure.

Pour un exposé plus complet, l'auteur aurait dû établir des liens entre les principes modernes d'administration qu'on retrouve dans les ouvrages américains contemporains et les notions qu'il a élaborées. L'absence de ce rappel d'auteurs américains est manifeste dans la courte bibliographie qu'il donne. Les noms d'Ernest Dale, Harold Koontz, Cyril O'Donnell, Chester Barnard n'y apparaissent même pas.

Malgré ces lacunes, cette tentative de synthèse demeure valable puisqu'elle commande la réflexion, incite le lecteurs ò repenser des notions acquises. Les principes émis peuvent servir de guide dans l'aménagement de structures autres qu'européennes Un nombre imposant de définitions peuvent être utilisées pour traduire la réalité structurelle d'une entreprise en contexte américain. Les praticiens de la gestion et professeurs pourront renouveler leur arsenal de connaissances et faire usage utile de l'ouvrage pourvu qu'il soit judicieux.

\section{Laurent BELANGER}

\section{A History of British Trade Unions since} 1889, Volume I - 1889-1910, H.A. Clegg, Alan Fox and A.F. Thompson, Oxford University Press, Londres, 1964. 514 pages.

La seule étude d'importance sur I'histoire du syndicalisme en Angleterre, celle de Sidney et Beatrice Webb, History of Trade Unionism, parut pour la première fois en 1894, et les éditions postérieures n'ont apporté que peu de chose. Aussi, désirant relater I'histoire complète des syndicats anglais, les outeurs ont cru bon de décrire le mouve- ment d'avant 1889, pour ensuite analyser à fond la période 1889-1910 dans leur premier volume.

C'est durant cette période que la négociation collective prit une forme définitive; que les unions aidèrent à créer ce qui devait devenir l'un des deux plus importarits partis politiques anglais. De plus, ce sont les conflits industriels aigus des années '90 qui ont amené les luttes parlementaires où fut déterminé le contexte légal dans lequel évoluent encore les unions. En somme, cette période constitue une phase cruciale de la formation du mouvernent syndical moderne et des systèmes de relations industrielles que nous connaissons aujourd'hui en Angleterre.

Successivement, le volume traite de l'offensive des nouveaux syndicats industriels et généraux et de la première contre-attaque des employeurs; de la situation syndicale dans les industries du charbon et clu coton; des modèles de relations de travail existant ò la fin du siècle; de l'action parlementaire telle qu'envisagée par le T.U.C.; de la représentation des travailleurs au parlement et du socialisme; du contexte légal jusqu'à l'époque du jugement Taff Vale; des effets de ce jugement sur la négociation collective dans différents secteurs; de la situation politique de 1900 à 1910; de la montée du mécontentement industriel après le jugement Taff Vale; et enfin de l'évolution générale du mouvement pendant la période étudiée.

Ce travail est une histoire complète: tous les foits importants y sont inscrits et la documentation est très poussée. II est possible de différer d'opinion sur certaines interprétations, mais la compétence des rédacteurs en garantit le sérieux.

Contrairement aux Webb, Clegg, Fox et Thompson $n^{\prime}$ inscrivent pas cette histoire dans le cadre d'une théorie générale du syndicalisme et cela leur permet des interprétations plus libres. Ce volume peut être considéré comme le pendant de ceux de John R. Commons sur le syndicalisme américain.

\section{Emile VALLEE}

Inflation: Demand-Pull or Cost-Push ? Edited by Richard Perlman, D.C. Heath and Company, Bostorı, 1965. 130 pages.

L'apporition de I'inflation aux Etats-Unis due à la guerre du Vietnam est le fait économique le plus important qui se soit produit depuis un an, estime le rapport annuel de la Banque des règlements internationaux, publié lundi matin, le 13 juin 1966, à l'occa- 
sion de l'assemblée générale de cet organisme.

On peut donc noter dès à présent l'à-propos de cette publication, la septième d'une série d'études en économique sous la direction éditoriale de David E. Novack de I'Université Cornell. Ce volume veut atteindre surtout la clientèle étudiante et faciliter lo tâche professorale en fournissant un éventail de points de vue et d'avis donnés par des personnalités en la matière tels: Richard Perlman, Walter A. Morton, Charles Schultze, Gardner Ackley, Fritz Machlup, Willard L. Thorp. Richard E. Quandt et Roberto De Oliviera Campos.

Le phénomène de la dévaluation de la monnaie ou de la housse excessive des prix est traité en tenant compte continuellement de son double aspect: demande excessive (demand-pull) ou poussée des coûts (cost push). On note que l'un des indices nous permettant de distinguer les deux théories principalement admises est la façon dont on explique la présence du chômage dans le processus inflationnaire.

- Dans une économie de libre entreprise, la décision de hausser les prix est prise par I'homme d'affaires qui réagit aux pressions économiques ou aux opportunités en haussant le prix des marchandises qu'il vend $x$. Les économistes ne s'attardent pas cependant d̀ cette cause immédiate de l'inflation. Ils la considèrent simplement comme une réoction oux causes premières qu'ils esaient de trouver et d'évaluer.

Etant donné la complexité évidente du phénomène, les études sur le sujet sont à la fois fragmentaires et complémentaires. L'une s'attarde sur l'influence des unions ouvrières ou sur la relation entre le plein emploi et l'inflation, une autre sur les politiques d'investissements et de profits des compagnies, une autre sur la relation entre la hausse des prix, le chômage et l'inflation. De la même façon, les experts s'interrogent également sur les mécanismes de prévention et de contrôle de l'inflation.

Pour l'étudiant intéressé à se familiariser rapidement avec les divers éléments de ce problème et les diverses façons de l'aborder (ex. approche macroéconomique de Gardner Ackley et approche microéconomique de Fritz Machlup), la lecture de ce volume peut constituer un atout important pour la compréhension des problèmes économiques.

André PETIT
Labor Market Institutions and Wages in the Lodging Industry, John P. Henderson, Michigan Stote University Business Studies, 1965. 227 pages.

A text at once impressive in its scope and somewhat unique in its subject matter. This study by Professor Henderson might immediately suggest to the Canadian reader the question of why a similar study of this area be not pursued here in Canada.

An excellent opening chapter on the relative and growing importance of the services industries is gradually followed by examination of the economic structure of the lodging industry wherein: " the large number of active proprietors in the (lodging) industry make it one of the last bastions of small individual enterprise in the American economy », although corporations are continually expanding in this field.

The substance of the work is to be found in the ensuing chapters dealing with the labor market institutions in the industry, the wage structure, the minimum wage controversy, a chapter dealing with the origins and growth of the hotel and restaurant employees and bartenders international union, the application and relevance of the national labor management relations Act to the lodging industry and a final chapter in which the author advances the thesis that resistence to minimum wage legislation will decrease and «larger establishments will no longer be able to cling to the ideal that the lodging industry is somehow apart from the main stream of American enterprise 》. Certain " immunities » now prevailing in this industry will, according to the author, slip away and changing patterns will cause labor market institutions and wage levels to become more integrated with the rest of the American economy.

But again in reading this at times fascinating ocount of labour conditions in the lodging industry in the United States, one is prompted to ask if work of a similar nature should not be carried out so that we in Canada can see the state of affairs prevailing in our own lodging industry and perhaps gain o perspective of future labour relations and labour legislation in this important and growing service industry. For in examining such questions as age, sex and ethnic composition of the labour force, hours of work, tipping vs regular pay, minimum wage application and provision, and a host of other labour market conditions, one sees that Professor Henderson has brought much. to light and one is left hoping that some 